IRA-International Journal of Management \& Social Sciences

ISSN 2455-2267; Vol.11, Issue 02 (May 2018)

Pg. no. 60-68.

Institute of Research Advances

http://research-advances.org/index.php/RAJMSS

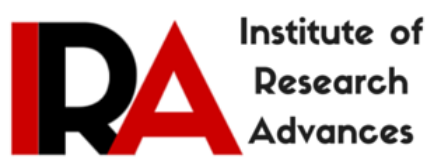

\title{
Divergent Struggles for Identity and Safeguarding Human Values: A Postcolonial Analysis of Chimamanda Ngozi Adichie's Half of a Yellow Sun
}

\author{
Aisha Mustapha Muhammad MA English \\ Lovely Professional University, India. \\ ORCID ID: http://orcid.org/0000-0001-8476-4355
}

Type of Review: Peer Reviewed.

DOI: http://dx.doi.org/10.21013/jmss.v11.n2.p1

How to cite this paper:
Muhammad, A.M.(2018). Divergent Struggles for Identity and Safeguarding Human Values: A Postcolonial Analysis of Chimamanda Ngozi Adichie's Half of a Yellow Sun. IRA-International Journal of Management \& Social Sciences (ISSN 2455-2267), 11(2), 60-68. doi:http://dx.doi.org/10.21013/jmss.v11.n2.p1

(C) Institute of Research Advances.

\section{(cc) BY-NC}

This work is licensed under a Creative Commons Attribution-Non Commercial 4.0 International License subject to proper citation to the publication source of the work.

Disclaimer: The scholarly papers as reviewed and published by the Institute of Research Advances (IRA) are the views and opinions of their respective authors and are not the views or opinions of the IRA. The IRA disclaims of any harm or loss caused due to the published content to any party.

Institute of Research Advances is an institutional publisher member of Publishers Inter Linking Association Inc. (PILA-CrossRef), USA. The institute is an institutional signatory to the Budapest Open Access Initiative, Hungary advocating the open access of scientific and scholarly knowledge. The Institute is a registered content provider under Open Access Initiative Protocol for Metadata Harvesting (OAI-PMH).

The journal is indexed \& included in WorldCat Discovery Service (USA), CrossRef Metadata Search (USA), WorldCat (USA), OCLC (USA), Open J-Gate (India), EZB (Germany) Scilit (Switzerland), Airiti (China), Bielefeld Academic Search Engine (BASE) of Bielefeld University, Germany, PKP Index of Simon Fraser University, Canada. 


\begin{abstract}
In the novel Adichie uncovers the characters' struggles based on the loss of Identity and Human values which is basically the result of the Nigerian civil war. The characters strive to bring back what they lost due to the war. Chimamanda Ngozi Adichie was born much later after the Nigerian civil war of 1966-1969. Chimamanda Adichie had the interest to revive history of the war; she used her imaginative talent in bringing what she hadn't experienced. The novel Half of a Yellow Sun is a literary work which uses the theory of post-colonialism or post-colonial studies, it is a term that is used to analyze and explain the legacy of colonialism through the study of a particular book. Colonialism did not happen during the colonial era only but extended to after independence of the countries that were colonized. The novel Half of a Yellow Sun shows the effect of colonialism after independence of Nigeria. Adichie believes that by bringing back the issue of the war, the growing generation would understand more about the war. According to her in Nigeria the history taught in the primary and secondary schools is not complete, some parts were removed and nobody is allowed to talk about it. So through the novel, she tries to go through history to see what has happened, so that she can make the young generation understand history better. The book opens with a poem by Chinua Achebe about the Nigerian civil war.
\end{abstract}

Keywords: Post colonialism, identity, politics, human values, violence, love, cultural ebb.

\title{
Introduction
}

\section{Post-colonial Literary Movement}

Post-colonial literary movement is a movement that started after the Second World War. Many countries that were under colonization got independence, writers from sub-regions emerged, example of such countries are; India, Caribbean, South Africa, Nigeria etc. In Nigeria post-colonial literature are works that are written during colonialism or after independence of the country.Fronts Fanon in 1961 wrote a book called The Wretched of the Earth in French, the book examines the anti-colonial violence that was happening or happened after colonization all over the world. Berry acclaimed that "For centuries the European colonizing power will have devalued the nation's past seeing its pre-colonial era as a pre-civilized limbo or even as a historical void"(2017: 86). He also ascertains that children should be taught history from the beginning before colonization, there shouldn't be differences between the blacks and the whites.

Another post-colonial literary theorist who changed the world's view is Edward Said, his greatest contribution to the world is the publication of his book "Orientalism"published in 1978. According to him the word "Orientalism" is a western conception about the eastern part of the world, as he wrote "“"Orientalism" was ultimately a political vision of reality whose structure promoted the difference between the familiar (Europe, West, US) and the strange (The Drier and East "Them")" (2001:38). Oriental is a person who is represented as feminine and weak, incomparable to the whites who are masculine and strong. Said, said the westerners divided the world into two parts, the "east" and the "west", "orients" and the "occident". They lay the basis of the concept of "them" and "us". Orient applies to all that is eastern and occident applies to all that is western, these concepts are opposite to each other like male and female, master and slave, colonized and colonizer etc. According to Said, colonialism is a powerful instrument which differentiates between Europeans and non-Europeans. The purpose of orientalism is to enhance and to strengthen the interests of imperialism or strengthen the imperial practice. He used Michael Foucault's notion of 'discourse' to define Orientalism, he said orientalism as a colonial discourse becomes a powerful instrument to give knowledge about culture and civilization, history and others. He also observed that colonial discourse can be understood by looking at the relationship between colonizers and colonized. Colonial discourse is a form of knowledge in which colonial people would be able to understand themselves, their identity and what made them subjective. The main aim of oriental discourse according to him is to create opposition or binary division in which Europe own their identity.

\section{Role of Identity and Politics in Postcolonial Nigeria}

The gathering at Odenigbo's house brings about the role of identity and politics in postcolonial Nigeria. In the house young people gather to discuss the political future of the country, in the meeting the importance of several kinds of 
African system of government is discussed amongst the educated people (Odenigbo and his friends). Odenigbo has always tried to defend the ideal unity for Africans, and his colleagues have always stressed upon the pan Africanism or nationalism. Odenigbo said the white people have always claimed that they are the ones that created what is called Nigeria, he used to say the real African man has existed since before the white man came, according to him they created what is called "black" as much as possible in order to differentiate themselves with the blacks. He also said he was an Igbo man since before the emergence of the white man. The role of identity can also be seen in the character of Kainene, she was given a name which was partial since her birth because she is not as beautiful as her sister, this makes her lose her identity in the family, and she always feels out-casted.

The Nigerian politics after independence of the country is said to be unstable because the Igbos think that the Northerners have occupied all the major parts in the governmental offices and have filled the country with corruption, this has resulted in the loss of identity of Igbos who feel that they are not a part of the country any more.In the novel Half of Yellow Sun Professor Ezeka said "It was mostly Northerners who were in government, Professor Ezeka whispered" (2007:125). In trying to find their real identity Ojukwu fought against the government, he had no arms, no weapons to fight: only wooden sticks; he deceived and risked so many lives that depended on him, Kainene said that "Madu told me today that the army has nothing, absolutely nothing. They thought Ojukwu had arms piled up somewhere, given the way he has been talking" (2007:183). The postcolonial Africa is in confusion since after independence, just like Edward Said has also stated the idea about 'identity'; the characters in the novel are in search of their identity which has been ruined by the 'Us' (Europeans)and led to so many deaths in the novel.

Even though the 'Us' (Europeans) are not in the country they indirectly control the people using their manipulative way. The westerners have a great influence on Biafran war but there is subtle critique found in Richard's character. Richard's intention is clean; Adichie is trying to show that not all the westerners are bad. He tries very hard to be a part of Nigeria and later part of Biafra too.His interest with the culture is also something good, he speaks for Biafra and also tries to help them, he also wrote to the Western press. Adichie is showing her talent in creating a character that will make the 'Us' not feel bad. The westerners are not in the country but all that is being taught in schools are planned by them. When Odenigbo was relating to Ugwu what will happen in his school: this is a clear domination of the Europeans, what Ugwu will be taught in the school and what he must say to pass his examination, "They will teach you that a white man called Mango Park discovered River Niger, which is rubbish, our people fished in the Niger long before Mango Park's grandfather was born, Odenigbo" (2007: 11). Susan is the real representation of the westerners' conception of the orients. Through her Adichie drew the map of how they look at all the orients. The westerners are living in Nigeria like Susan, owning most of the wealth and still referring or calling them savages and uncivilized, "The people were bloody beggars, be prepared for their body odors and the way will stand and stare at you...never show weakness to domestic staff" (2007: 54).

Edward Said has said on cultural hegemony that the westerners have always been considered to be superior and the easterners as inferior. Major Madu asked Richard to write a letter to the British in order to voice out their sufferings for external support, he asked him to do that because according to him they will be listened to, if a Westerner is in support of them, the Europeans would help them. The Westerners are also seen as superiors because the Biafrans think that if they will support them, everything would be settled. Just because of Richard's letter two journalists were sent away from England to Nigeria. They considered one dead European man to be equal to one hundred black men. One of the journalists who were sent to Nigeria said that the African women are said to have sexual transmitted disease and it is through this instance Adichie shows how the Europeans look at the African women. Another European journalist also said the blacks don't have the sense of what to eat, just because he saw Biafran children eating roasted rats, he didn't think that they are in war and don't have food and meat to eat but only rats and lizards as substitute of meat.

\section{Struggles for Safeguarding Human Values}

In the novel the characters suffer the issue of violence because of the war.

Were you silent when we died? 
Did you see the photos in sixty-eight?

Of children with their hair becoming rust:

Sickly patches nestled on the small heads,

Then falling off, like rotten leaves on dust!

Imagine children with arms like toothpicks

With footballs for bellies and skin sketched thin

It was Kwashiorkor difficult word

Their skin had turned the tawny of weak tea

And showed cobwebs of vein and brittle bone; (2007:375)

Through the lines of the poem the reader's attention is drawn to the brutality of war. Chinua Achebe has said that Adichie was 'fearless'(2012: 30) to uncover what has been hidden for a long time. Achebe said: "I do not agree I believe that in our situation, the greater danger lies not in remembering but in forgetting" (2012:30). According to Ojinmah "Adichie refused to forget, one of the fundamental functions of the writers is like those of story tellers in traditional African society" (2012:4). Also according to Dickson "Articulating in writing the horrors of the war as stored in her memory through stories she was told by her parents and relatives, and written accounts of the war, serves a cathartic process"(2014:86). Adichie uncovered the realities of war at the beginning of the novel before going into psychological and emotional face of the story.She presents the explosion of the North-South war as an important moment which does not just offer the history but also functions as a stepping stone into the psychological mind and emotions of the individuals on the effect of war, which also affected the relationships, ethnic groups and the nation as a whole. The psychology and emotions of the characters also inter wined with the moment when they realized how the war has affected them. The story is also considered as a melo-drama, using humor to pave the way. The novel is a presentation of the civil war deeply. The history travels through the deepest root of the war, the conflict, injustice, violence and the pain of war. Adichie uses the theme of humanity to voice out the issue of the civil war. The characters struggle with the issue of love, class, race, profession etc. "Half of Yellow Sun is a novel that two different things comes together; fiction coexists with war. She presents the untruth which the historians hide from people “ (Requel, 2016: 1).

Adichie through the characters has shown the clear picture of the Biafran war, one is made to travel to the time. The characters have suffered because of the violence which was caused by the civil war. Violence is first introduced in the first part of the novel, Adichie opens the book as a comic one, with Ugwu and his Aunt on the way to his new masters' house but at the end of part one, she introduces a book called The world was silent when we died; this creates a new atmosphere to the reader, the novel which looks like a happy novel now looks different. After the first coup, two weeks later the Northerners come into power, this was the appearance of violence in the novel. Kainene heard in the radio that so many Igbo's were killed in the north, Zaria, Kano and Kaduna; she became worried because her childhood friend Major Madu is in the north, they try contacting him but they were unable. Kainene's friend Colonel Udochi Ekechi was killed in the north. Major Madu escaped; he narrates how he had suffered, so many of his friends were killed, his friend: a Hausa man helped him; he took him to his cousin's house where he spent some days in the chicken room and then escaped in a water tank, which almost killed him. According to him so many innocent men were killed, even Udochi who doesn't care about tribalism, who speaks Hausa fluently and never encourages the coup, was also killed. Odenigbo heard in the news that over five hundred Igbos were killed in Maiduguri. Some men also come to the village and narrated what they had seen in the railway station. Odenigbo asked Ugwu to take some bread to the railway station to the wounded who had escaped from the north, the first man which Ugwu saw was wounded on the head with knife and the second had lost his right eye, this is an extreme violence caused by the war. 
Olanna who was in Kano was rescued by her ex-boyfriend Muhammed. She visited Kano in order to bring her cousin sister Arize who was due to give birth, she wanted her to give birth in Nsukka, but unfortunately the war caught her there. Muhammed asked her to put on the Muslim Hijab, so that she would not be recognized, he took her immediately to the railway station so that she would be able to escape. On their way she insisted on going to Sabongari to check on her Uncle's family, she saw her uncle and his wife's body lying on the ground dead, blood was running all over the place, the entire street was covered with blood. Olanna in the train saw so many people injured, she met a woman carrying calabash. The woman later opened the calabash, Olanna saw the head of a baby still plaited new, the violence did not only affect adults, but children were also killed, "Olanna looked into the bowl; she saw the little girl's head with ash grey skin and the rolled eyes and open mouth. The mother said "Do you know, she said, it took me long time to plait her hair! She has such thick hair" (2007:149). Such were the great struggles of the characters which were caused by the war in the novel. People were killed innocently because of the so called 'BIAFRAN WAR', the war did not bring any good to the country; it only led to their suffering and so many killings. Another incident of violence was the one Richard encountered when he was coming back from London and he branched in Kano, he met a young man called Nnameka, with whom he chatted with for some minutes, the man was full of dreams, he told him that his family depended on him, but before you knew it the soldiers come into the airplane and shot him, just because he was an Igbo man, they killed so many people in the plane at that time.

When the war was declared, Odenigbo and his family had to leave Nsukka for their safety, they moved to Abba his parental village. Odenigbo and Olanna had to leave everything in Nsukka, they only packed little that they needed. Olanna's parents also left Lagos to London. So many people started leaving the cities to the village because the Nigerian army had spread all over the town of Nsukka. Moreover Odenigbo's family had to leave Abba because it was not safe anymore, he begged his mother to follow them to escape but she refused, they went to Umuhia where they stay for some time. Olanna and Odenigbo in the midst of their suffering decided to marry, Odenigbo had always dreamt of a grand wedding, but because of the war they only invited few people. On the day of the wedding after the marriage in a "tiny church", there was bomb; people that gathered for the wedding ran for their lives, there was no reception because everything was ruined. Olanna was not happy because no one in her family attended the wedding. On page 258 the author of the book The World was Silent when we Died ${ }_{2}$ explains to the readers how the Biafrans died. They died according to him because of the lack of support from other countries, they all supported the Nigerian government, which tried to eradicate the Biafrans, even France which sold some weapons to the Biafrans did not support or recognize Biafra. This is the reason that led to the downfall of Biafra and violence.

Olanna grew up in a luxurious home with abundance of everything, Olanna had to cope with the situation because she intentionally refused to follow her parents, and instead she followed Odenigbo. Baby became sick and Olanna was disturbed thinking that the child will die, money becamea problem to the Biafrans because of the new currency they had introduced which they called the 'Biafran pounds', Olanna had to follow a long queue for her to be able to get the money. MrsMukelu brought some egg yolk, which they gave tobaby and it helped her to regain her health. Olanna had to follow a long queue to get those dried egg yolk. She met a man whom she knew, who collected the egg yolk for her and gave her some corn beef she thought of cooking it for her family, but some group of Biafran soldiers followed her and snatched the corn beef from her. The war ruined their lives, food became scarce, and rice was not available in the market because not all people could afford to buy it. Hunger became rampant everywhere, the office that provided food for them didn't give them every day, so the day the food was not given; the children stayed with hunger. As mentioned earlier, the war did not only affect the adults but also teenagers and children. It corrupted the mind of the children with bad thoughts. Olanna in her class introduced the Biafran flag with its meaning, which had three colors, "red was the blood of the siblings massacred in the north, black was for mourning them, green was for the prosperity Biafra would have... (2007: 281). A girl in her class when submitting her drawing said she would kill the vandals. Olanna felt bad and guilty for teaching the girl all this, which she later complained to Odenigbo. This was misguiding and teaching violence to young children to hate the northerners; this would lead to another problem.

The violence had gone to the extent that Umuhia was also not safe and so many schools were closed and turned into refugee camp, there was no living school. This was bad, the children no longer could go to school; education became history in their cities. In the refugee camp Ugwu met so many people that made him feel sad. A woman narrated that she was in the market when the war started, she was only able to escape with the clothes on her body, the baby she backed and some money she had for selling pepper, she ran and left all her children because she was 
not allowed to go back home, she doesn't know what had happened to them, Ugwu pitied her. He also smelt something awful, he then realized that one woman had used water in a bowl for so many days to wash her cassava, this is true cruelty not only hunger is the problem but also hygiene, the water could cause so many harmful diseases, which may lead to their death. Port Harcourt was considered to be Biafra's support and strong army, Kainene and Richard lived there, rumor spread that it would also soon fall, they didn't believe at first, but one afternoon they were attacked and one of their houseboy was killed called Ikejide, Kainene was left in great shock because she saw the boy's head separated from his body, this was the reason why they left for Orlu, where she had bought a new house. There she met a man who could do carpentry work, without him asking her for money, he told her that he only needed food to survive. In the country of Biafra money was a waste, one wouldn't be able to buy anything even if had the money, "Why don't you want money? Kainene asked him "what will I buy with money" he asked" (2007:317). Kainene and Richard also helped some people in one refugee camp; they gave them food and even called doctors for them. There was also a pastor in the camp who preached the people to give them some hope. Inatimi was a man they met who appeared to be a foolish guy, he talked nonsense, this was because he had lost all his family members in the war, and he said he didn't have anybody to remind him of the past.

The war also started to take a new dimension; besides hunger people started to lose their manners. Odenigbo was asked to vacate his two room apartment because the landlord had got a new tenant who would pay twice the money, accommodation started becoming problem for the people. They got a house which had nine rooms, one bathroom and toilet; almost all the people in the house were refugees. "There were too many people in the yard; a family of sixteen lived in the room next to Mama Oji, the bathroom floor was slimy with too much dirt washed off too many bodies" (2007: 326). There was over population in the compound which made the tenants aware of all what other people were doing, there was no privacy at all. Olanna's room was next to the toilet, it was unbearable for her at first because of the smell, she always wished there was a fan in their room, there was no electricity at all, unlike the house they left; she had never experienced such in her life. She also met uneducated and uncivilized people, first was Mama Oji, who thought that being a doctor meant medical doctor, until Olanna explained to her that Odenigbo was not a medical doctor but book doctor. Also because of overpopulation the compound became so noisy, whenever Mama Oji was fighting with her husband; she doesn't allow them to rest because of her shouting. Olanna also had to endure the Pastor's loud praying which he did all the time. There was also a girl who played piano every day, her name was Alice, she also disturbed Olanna because her room was next to hers, they also followed queue when they had to go to the toilet.

Kainene ran a refugee camp where she helped the people to get medicines, crayfish and some food stuffs which was serves as a great help to them. When Olanna visited her, she took her around some of the refugee camp, Olanna was shocked on seeing how people were dying, mothers dying living their children, she felt pity for them, according to Kainene countless people die every day. Kwashiorkor became everywhere, at the compound of Olanna, a girl Adanna had a fever and she realized it was kwashiorkor and gave her some milk. In the camp they visited, they also saw so many children with the disease; Kainene told her that it was lack of protein. Innocent young teenagers were dragged to the war field because in 1968 many of the Biafran men were killed. Ugwu is also dragged on the road, without asking for his opinion they forced him inside the lorry. Ugwu is shocked when he met a young boy who was not more than thirteen years, the boy was drinking alcohol, this was very bad, the boy that was supposed to be in school under the care of his parents, but he drank alcohol and was exposed to danger of war. The name of the boy is 'high tech', the boy is so proud of himself, that he is a warrior, it is childishness because he thinks that everything is a game. The war has not brought any good but rather the fall of the Igbo society. The children do not only suffer separation from their parents but also they were also exposed to wrong doings, they do not know its disadvantages. Their schools were also turned into training centers for the Biafran soldiers. Ugwu was taken to the center; Ugwu's first experience shows the sign of brutality, which is the first part of his struggles.

"The skinny soldier -with no boots, no uniform, no half of a yellow sun on their sleeves kicked and slapped and mocked Ugwu during physical training. The parade left Ugwu's arm stiff. The obstacles training left his calves throbbing. The rope climbing left his palms bleeding"(2007: 359).

Ugwu also realized what Professor Ekwenugo described about what the battalions have for the war, he was so happy at first to be among the battalions who would fight for Biafra, but was disappointed because they didn't have the 
weapons to fight the vandals, that is why so many of the Biafrans army were killed, "But when he went to the first training session, he stared at what was before him: a dull metal container full of scrap metal" (2007: 359). Ugwu then realized that they were just offering themselves to be killed because they didn't have guns. The boys together with Ugwu were bullied all the time. Eberechi Ugwu's friend, whom he secretly loves, is someone that was exposed to prostitution, she was sold to the soldier, in exchange of money because of poverty and also the commander helped her brother to join the army. This is the struggle the women in the novel suffered; they were exposed to men because of poverty, some of the girls take themselves willingly to the soldiers in the camp, the young girls that are supposed to be in school or married became prostitutes, this was the effect of war. Ugwu said "Sometimes younger women come and went in the commander's quarters and emerged with sheepish smiles" (2007:360). The young boys are not only exposed to drinking alcohol, but also to smoking of weeds, marijuana and so on. The war spoilt the behavior of the young children, they smoke in front of the commander and he always felt happy and praised them, and the young soldiers are also exposed to robbery. They rob and maltreat the civilians; they even beat some and collect their money. On their way to the bar Ugwu and his friends stopped a man in his car, even after showing them his Biafran identity movement card, they didn't listen, they slapped and collected his car keys and drove away, this is the struggle they have to go through; they have to live in that way for them to survive. Ugwu said "He was not living life but life was living him" (2007: 364). They were all not happy with their lives but had to endure it due to circumstances. They arrived in the bar, got drunk and gang raped the bar girl, together with the thirteen year old boy high tech, this is the effect of war. Ugwu never wanted to do it, but because he didn't want them to tease him and call him someone that is disabled that is why he joined.

Muhammed wrote to Olanna and sent her some gifts which she shared with some of her neighbors. The only person that eats thrice is Baby; they only eat once or twice a day. Olanna use to pity Odenigbo because he is man who likes fashion and also drinks the best beer, but he now only drinks the local gin, he smells bad and has only two shirts and a trouser. Alice the girl, who lived in the same compound with Olanna, told Olanna that all her family members were killed by the vandals. Her state had also fallen, she cried a lot when she was narrating the story. Even though Kainene tried her best but the situation becomes so bad, the children in the camp now eat only once in a day, and the food is 'garri'. The suppliers were not able to cross mobs to find some garri for the refugees. Hunger started becoming worst; they now eat lizards as meat. They also don't have water to use, talk less of taking bath. Kainene is so worried because the refugees now smell badly, she even asked them to use orange from the tree to drink and rub it on the back of their bodies, according to her the scent of the orange will reduce the smell of their bodies.

The Southeast of Nigeria, has the highest rainfall in the country, because of the heavy rainfall it becomes almost impossible for the people to do farming extensively, which makes them rely mostly on the North for grains of food such as rice, maize etc. So when the Nigerian government commanded all the roads of supplying of food for the Biafrans to be blocked, the food became scarce, they were not able to farm; this increased the rate of hunger during the war. Ugwu was luckily rescued by some thugs, he suffered a lot during the war and everyone had thought that he had died. After the thugs took him, they didn't give him water, which made him wish to have died than been denied water, he spent days without water. He has wounds all over his body that made it impossible for him to be able to move his body, he was taken to the hospital where he saw so many wounded people. The issue of adultery became rampant during the war, this is seen in the refugee camp in Orlu, one girl was impregnated by an elderly person, who used to sleep with girls in exchange of stock fish. Ugwu who always poked nose in all that is going on around him became very quiet after coming back from the war, he no longer wants to hear people talking about the war, he usually sits alone and talks to himself.

\section{Struggle for Love}

Adichie in the novel tries to show how the characters took love in the novel, how their love is shattered, and also shows how strong real love is how one that is in love can sacrifice for the other. Love is a natural phenomenon that happens between two people, love is something that cannot be pretended, it exists naturally. Normally when two people are in love they sacrifice for each other. Adichie shows the romantic relationship of the characters in the novel, the love between the two sisters (Olanna and Kainene), Olanna and Odenigbo, Richard and Kainene, Ugwu's love to Nnesinachi and Eberechi. The love in the novel is being affected naturally or due to the political uproar. Olanna comes from a rich house, her father is a rich business man, but the issue of love in the house is absent, Olanna feels more comfortable when she visits her uncle's house in Kano, even though they are not rich but there is 
an atmosphere of peace and unity which is bounded by love. Their life is simple they are not faking life like her parents, this makes Olanna and Kainene to distant themselves from their so-called 'rich family'. Odenigbo's house is a paradise to Olanna because of the love they share between themselves, even though sometimes he stays in the library for the whole day to study. Susan's love for Richard is real but he has to leave her because he doesn't feel the same, Susan has to struggle because of her love for him.

Adichie divided her story into three sections. In the second phase, the sisters' share some bond of love not like in the first section and also Kainene wrote to Richard longing to see him, this is showing that something must have happened in one way or the other. Ugwu from the start of the novel has a strong attraction to girls. As a child he had fallen in love with his cousin Nnesinachi whom he was attracted to because of her beauty, was attracted by her looks, and had always wanted to touch her. Nnesinachi is a cousin to him but his mother told him that she is like a real sister, which makes it impossible for him to have her, Ugwu has to suffer separation of love because Nnesinachi has to leave for Kano to stay with her uncle's family. Ugwu later met Cinyere, whom he never had feelings for but have sex with and always imagine her to be Nnesinachi. Ugwu falls in love with Eberechi, he loves her but was more attracted to her body, she has a round buttocks. Ugwu's love for Nnesinachi and Eberichi is shattered because of the war; he is separated from Eberechi and taken to war. Odenigbo's love is disintegrated because of the war, he became an addict, he neither talks to Olanna nor smiles to her. In Kainene's house he talks arrogantly and Olanna said that he has not been himself since the beginning of the war, the love of the couples was taken away; Odenigbo doesn't even have time to talk to his wife. Odenigbo became a little insane, not repaying Olanna for what she did, she would have followed her parents to England but she stays with him. Olanna has to struggle because of his change of attitude, "I want this war to end so that he can come back, he has become somebody else" (2007:388). The absence of love in Olanna's family was the reason her father cheated on their mother, when Olanna went to talk to her father about the issue, there was emptiness of closeness between her and him, she pitied them all, and their life; "Olanna felt a sudden pity for him, for her mother, for herself and Kainene" (2007: 219). Even though Odenigbo betrayed Olanna and she also did the same but the strong bond of love between them is unbreakable, she forgives him and also adopts his daughter as hers. The love between Kainene and Richard is also alluring in the book.

\section{Physical Indisposition of Cultural Ebb}

The characters go through physical indisposition of cultural ebb of their society. African countries are considered to be the countries that have a lot of culture and tradition. Nigeria having more than 400 ethnic groups makes it possible to have different set of people, with different believes. Their cultures are governed by set of rules, which they always maintained before the coming of British colonizers to the country. The British colonizers bulldozed the southern part of the country, introducing so many things that didn't exists before. Adichie in the novel shows how the characters struggle because of the dying of their culture. The story opens with Ugwu's Aunty telling him how his master is; he has spent most of his time on reading books of overseas according to her, and hardly returns greetings, this is entirely something different in relation to the tradition of the Igbo society; they respect greetings and always return greetings. The idea of Ugwu's attraction to his cousin sister is totally different from Igbo culture, it can be said that going to the primary school in his village corrupted his mind. Ugwu's master asked him to call him with his first name which is totally absurd and unacceptable in his villages, he felt awkward because he never calls his elders with their first name. Ugwu never got the courage to call him with his first name till the end of the novel. Ugwu's aunt describes the women in the university; she says they are always with wigs and mini-skirts. The traditional village people don't put on mini-skirt, that's why she is telling him because it is something new he will see. Miss Adebayo a friend to Odenigbo who always comes to their meeting every Saturdays in his house together with other lecturers, has some manners which is also very different to the traditional African woman, Miss Adebayo's way of talking is different because she raises her voice above all the men present in the meeting which Ugwu finds inappropriate, but because she is an educated person, she feels what she is doing is right. Olanna's parents' meeting with the minister Chief Okonji is also something disgraceful, instead of the parents to look for a young and handsome man to marry their daughter to, but rather they want to push her to sleep with an old man, the age mate and partner of her father. 


\section{Conclusion}

Adichie has shown how the characters struggle for identity, which was lost by the politics of the country and the intervention of the westerners in postcolonial Africa. The struggle for safeguarding human values was something very hard for the characters in the novel, they suffered violence because of the war, and their value as human being was taken away because of the war. The characters also suffered degradation of human values in the field of love between themselves. The study has shown that war is not the final solution to all problems but is just a way of deteriorating the society. The novel is not completely fictional because Adichie has gone back through history and presents what had happened forty years ago in Nigeria; she has shown how war has affected and destroyed the country's happiness. Through critical analysis the study has shown inwardly what Adichie is trying to pass on to the people that will try one day to take revenge on what has been done to their ancestors, Adichie has tried to be objective in her approach of the novel, she has not been biased in one way or the other, and she has shown everything that happened. She has presented how other tribes in Nigeria view the incident of 1967; she tries to show more clarity of what really happened, not a mere guess of everything that had happened. The Nigerian civil war is still a painful event because it has touched so many people and also affected the nation as a whole. Adichie told the story as a form of reconciliation of what happened during the reign of General Gowon. The story is said to be a success because the reader is able to travel four decades ago and feel and see what the people have gone through. Adichie presents the historical line of the Nigerian history - the war which led to violence and deaths of so many innocent people in the country.

\section{References}

[1]. Achebe, C.(2012). There was a country. London:Penguin Press.

[2]. Adichie, N. C.(2007).Half of a Yellow Sun.London: Harper PerennialPublishing.

[3]. Berry, P. (2017).Beginning Theory. New Delhi: Viva Books Publishing.

[4]. Dickson, C.B. (2014). History, Memory and the Politics of National Unity in Adichie's Half of a Yellow Sun and Achebe's There was a Country, 2, 81-90.

[5]. Fanon, F.(1980).The Wretched of the Earth.Harmondsworth: Penguine Publishing.

[6]. Makokha, G. A. (2014). Portrayal of the African Women in Half of a Yellow Sun,4,111-20.

[7]. Nixon, R. (2006, 1 October).Biafran story.The New York Times. Retrieved 2 February,2017 from

[8]. http://www.nytimes.com/2006/10/01/books/review/Nixon.t.html

[9]. Ojinmah, U. (2012). No Humanity in War: Chimamanda Adichie's Half of a Yellow Sun,1, 1-11.

[10]. Requel,S. (2016, 25 October). Half of a Yellow Sun is a powerful portrait of the Nigerian civil war.Cultural trip, Retrieved 20 February, 2017 from

[11]. https://theculturetrip.com/africa/nigeria/articles/half-of-a-yellow-sun-a-symbiotic-expression-of-fiction-and-history/

[12]. Roshan, K.(2014). Represention of History in Chimamanda Adichie's Half of a Yellow Sun,1.3,150-54.

[13]. Said, E.(2001). Orientalism. India: Penguin Press. 